\title{
Boris Šerginin pohjoinen
}

Artikkeli tarkastelee ekokriittisestä näkökulmasta neuvostoaikaisen kirjailijan

Boris Šerginin pomorien kansanperinteeseen perustuvista kertomuksista koostuvan tuotannon pohjoisen kuviteltua maantiedettä sekä sen suhdetta luontoon muun muassa kristinuskon ja neuvostomodernisaation konteksteissa. Se esittää, että Šerginin tuotanto rakentaa pomorien narratiivista identiteettiä, jolle keskeisiä ovat rikas elämä meren ehdoilla luonnonvarojen puolesta köyhällä alueella, kristinusko, vanha kulttuuriperintö sekä yhä uusien pohjoisten alueiden hallinta uusien teknologioiden avulla. Šerginiä Venäjän pohjoisen sakraalin maantieteen ja venäläisen kirjallisuuden pohjoisen tekstin kautta lukeva tutkimus on hahmottanut Venäjän Pohjolan kollektiivista identiteettiä keskittyen sen mytopoeettisiin merkityksiin. Tämä artikkeli tuo Šerginin materiaalisen ympäristön vahvemmin esiin ja tarkastelee Šerginin pohjoisen tekstin tutkimusta osana pomorien narratiivista identiteettiä.

Mika Perkiömäki

Arkangelista kotoisin olleen Boris Šerginin (1896-1973) vuonna 1971 kokoelmassa Gandvik - studjonoje more ("Gandvik - hyytävä meri", GSM) ilmestynyt kertomus "M. D. Krivopoljenova" esittää Pohjois-Venäjän paikkana, jossa venäläisen kansanperinteen runoelmat, bylinat, elivät pisimpään. Kertomuksen päähenkilön Marija Krivopoljenovan (1843-1924) se taas esittää Pohjois-Venäjän viimeisenä runonlaulajana. Kertomus kuvaa venäläisten pomorien saapumista Vienanmeren pohjoisille rannoille: "Venäjä [Rus] otti Novgorodin kansalaisten muodossa Pohjoisen hallintaansa jo 1300-luvulla. Lukutaidoton, mutta tiedonjanoinen Krivopoljenova kertoi Venäjän etenemisestä Pohjoiseen ikään kuin olisi itse osallistunut retkille"1 (GSM, 127). "Pohjoisen hallinta" (osvojenije Severa) on käsite, joka liittyy erityisesti Stalinin ajan neuvostomodernisaatioon, jonka tavoitteena oli "neuvostovallan avulla muuttaa tuntemattomat ja kesyttämättömät tilat sekä tunnetuiksi että valistuneiksi" (Widdis 2000, 404). Šerginin kertomus kuitenkin ajoittaa Venäjän pohjoisten alueiden haltuun ottamisen jo keskiajalle. 
Tässä artikkelissa kartoitan Šerginin kaunokirjallisen tuotannon käsityksiä pohjoisesta ja osoitan, miten siinä pohjoisen ympäristön haltuunotto kytkeytyy neuvostomodernisaatioon. Samalla Šerginin pohjoinen on kuitenkin paljon muutakin, ja kuten yllä oleva sitaatti osoittaa, siinä pohjoisen hallinta alkoi jo keskiajalla. Tarkastelen sitä, millaisena Venäjän pohjoisen luonnon vuorovaikutussuhde pohjoiseen ihmisasutukseen näyttäytyy ja mitä merkityksiä pohjoinen luonto saa sekä sitä, mitä "pohjoinen" ylipäätään näissä teoksissa tarkoittaa. Venäjällä tehdyssä tutkimuksessa Šerginiä on kuvattu niin sanotun pohjoisen tekstin keskeisimpänä kirjailijana, ja hänen tuotannossaan on pohjoisen luonnon todettu saavan usein Venäjän pohjoisen niin kutsuttuun sakraaliin maantieteeseen liittyviin myytteihin ja henkisyyteen yhdistyviä merkityksiä.

Sekä pohjoinen teksti että sakraali maantiede ovat venäläisessä tutkimuksessa viime vuosikymmeninä kehitettyjä käsitteitä, jotka esittelen artikkelissani. Ekokriittisen näkökulman kautta kurotan itse niille luonteenomaisten mytopoeettisten ja metafyysisten kysymysten yli ja selvitän, mitä ihmiskeskeisen luennan ulkopuolisia merkityksiä Šerginin pohjoiseen liittyy. Ekokritiikki on tutkimussuuntaus, joka 1990-luvulta alkaen on tarkastellut ekologisia kysymyksiä kirjallisuudessa ja muissa kulttuurituotteissa (ks. Lahtinen \& Lehtimäki 2008). Luen Šerginin tuotannon ei-inhimillistä luontoa esiin Serenella Iovinon ja Serpil Oppermannin (2014) kehittämän materiaalisen ekokritiikin keinoin. Siinä "fyysistä todellisuutta tarkastellaan erilaisten toisiinsa vaikuttavien järjestelmien ja toimijuuksien yhteenkietoutuneena prosessina" (Raipola 2015, 27-28). Materiaalisessa ekokritiikissä luontoa ei ymmärretä ihmisen vastakohdaksi tai ainoastaan ihmisen ympäristöksi vaan sekä ei-inhimillisten että inhimillisten toimijuuksien toisiinsa muutoksia aiheuttavana jatkuvana vuorovaikutusprosessina. Laajemmin taustalla on posthumanistinen ajattelu, jossa ihminen ei jäsenny ei-inhimilliselle vastakohtaisena tai ominaisuuksiltaan ylivertaisena (ks. Lummaa \& Rojola 2016) sekä niin kutsutun materiaalisen käänteen myötä esiin nousseelle uusmaterialismina tunnetulle paradigmalle tyypillinen tapa ymmärtää materia merkityksettömän ja passiivisen aineen sijasta aktiivisena toimijana (ks. Gamble, Hanan \& Nail 2019).

Šerginin tuotannon tutkimuksessa niin posthumanistinen, uusmaterialistinen kuin ekokriittinenkin näkökulma ovat uusia, sillä vallitseva pohjoisen tekstin venäläinen tutkimus on ollut antroposentristä ja myyttikeskeistä. Lukemalla materiaalista maailmaa ja ei-inhimillistä luontoa länsimaisen kirjallisuus- ja kulttuuriteorian avulla pohdin sitä, miten Šerginin pohjoisuuden käsitykset toimivat Venäjän pohjoisen paikallisen identiteetin muotoutumisen välineenä sekä sitä, mikä on pohjoisen tekstin ja pohjoisen sakraalin maantieteen tutkimuksen asema tämän paikallisen identiteetin kannalta. Lisäksi tarkastelen sitä, tukeeko Šerginin tuotanto ajatusta pomorikulttuurin ortodoksiuskosta kumpuavasta ympäristötietoisuudesta vai pikemminkin näkemystä siitä, että perinteisen pomorikulttuurin luonnonvarojen kestävä käyttö johtuu jostain muusta. ${ }^{2}$

\section{Boris Šergin ja pomorit}

Ennen kaunokirjallisuusanalyyseihin siirtymistä on tarpeen esitellä tutkimani kirjailija sekä hänen tuotannolleen keskeinen pomorikulttuuri. Laivanrakentajaisälle ja vanhauskoisesta suvusta tulleelle äidille syntynyt Boris Viktorovitš Šergin kasvoi Arkangelissa maailmaan, jossa kierrätettiin pomorien kansanperinteeseen yhdistettyjä satuja ja kertomuksia. Aikuistuttuaan hän kiinnostui tästä tarinaperinteestä syvemmin, alkoi kerätä pohjoisen kansanperinnettä ja muutettuaan 28-vuotiaana Moskovaan alkoi julkaista sitä kirjallisina kokoelmina. Usein hän 
muokkasi vanhoja tarinoita ja lisäsi mukaan myös omia pohjoisessa vietettyyn lapsuuteen perustuvia kertomuksiaan.

Šrginin tuotannon ydin koostuu yhdeksästä kertomuskokoelmasta, jotka julkaistiin vuosina 1924-1971. Monet kertomukset ovat ilmestyneet useassa kokoelmassa, toisinaan hieman muokattuina versioina, ja myös postuumisti on julkaistu useita erilaisia kokoelmia. Yhteensä näissä teoksissa on vajaat 200 eri kertomusta. Yli kymmenestä Šerginin kertomuksesta on vuosina 1971-2018 tehty myös animaatioelokuva, mikä on lisännyt hänen tunnettuuttaan.

Šerginin ensimmäiset, vuosina 1924-1936 ilmestyneet kokoelmat ovat enimmäkseen kansanperinteen ylös kirjaamista, omia kertomuksia niissä on vähän. Tyyli muuttuu vuonna 1939 ilmestyneessä kokoelmassa U pesennyh rek ("Laulujoilla", UPR) ja erityisesti sen toisessa osassa, joka sisältää missään muussa kokoelmassa julkaisemattomia pohjoisen tarinaperinnettä mukailevia lyhyitä tarinoita Leninistä ja Stalinista sekä pieniä kertomuksia esimerkiksi Gorkista, puna-armeijasta ja jopa Neuvostoliiton lipusta. Aikakaudellaan ne olivat teemoiltaan varsin tyypillisiä variaatioita Lenin-kulttia rakentaneesta neuvostomytologiasta, joskin pohjoisen näkökulmansa vuoksi omaperäisiä. Pantšenkon $(2005,19)$ mukaan 1920-30-luvun keksitty kansanperinne, niin kutsuttu "fakelore", Leninistä oli "neuvostoliittolaisen kansanperinteen" kehityksen ensimmäinen ilmentymä. Šerginin Lenin- ja Stalin-tarinat eivät yleensä kuitenkaan sijoitu pohjoiseen, ja jos sijoittuvat niin pohjoisuus ei ole niille keskeistä. Niiden pohjoinen kytkentä tulee siitä, että ne on kirjattu pomorialueelta kerätyiksi.

Seuraavassa kokoelmassa, vuonna 1947 ilmestyneessä Pomorštšina-korabelštšinassa ("Pomorinmaa - laivojen maa") neuvostomytologian rakentaminen jää vähemmälle, ja kriitikot pitivätkin sitä taantumuksellisena. Šergin ajautui syrjään Neuvostoliiton kirjallisesta elämästä ja hänen terveytensä heikkeni (Kaplin 2014, 17). Suojasään aikana hän pääsi kuitenkin piireihin takaisin ja julkaisi vuosina 1957-1971 vielä neljä uutta kokoelmaa, joista etenkin vuonna 1959 ilmestynyt Okean-more russkoje ("Venäläinen valtameri", OMR) menestyi hyvin. Šrerginin kaksi viimeistä kokoelmaa eroavat aiemmista kristillisten motiivien runsaudessaan.

Šrginin tuotanto kuvaa siis pomorien elämää. Pomoreiksi (ven. pomory) kutsutaan niiden varsinkin Novgorodista 1100-luvulta alkaen pohjoiseen muuttaneiden venäläisten jälkeläisiä, jotka asuvat Vienanmeren rannoilla ja sen ympäristössä. Pomorien asuttamat alueet Arkangelin ja Vologdan alueilla, erityisesti Vienanmereen laskevien jokien ympärillä, ovat juuri ne, joita Venäjällä on tavattu tarkoittaa Pohjolasta (Russki Sever) puhuttaessa (Lihatšov \& Janin 1986, 115). Hallinnollisesti tämä alue kattaa myös Nenetsien autonomisen piirikunnan sekä Novaja Zemljan kaksoissaaren ja asuttamattoman Frans Joosefin maan. Pomoreille erityisesti Novaja Zemlja on ollut tärkeää metsästysseutua. Sekä se että pomorialueen länsipuolella Vienanmeren vastarannalla oleva Murmanskin alue esiintyvät usein myös Šerginin tuotannossa. Näin pienelle alueelle rajoittuva käsitys Pohjois-Venäjästä jättää sen ulkopuolelle laajat alueet Uralin itäpuolella, jossa suurin osa maan arktista aluetta sijaitsee. Ajatus pomorien vaikutuspiiristä "Venäjän Pohjolana" on kuitenkin venäläisessä diskurssissa hallitseva. Se heijastaa sekä Arkangelin historiallista merkitystä alueen keskuspaikkana että Venäjän kulttuurielämän Eurooppa-keskeisyyttä. Siperian ja Venäjän Kaukoidän alueilla onkin oma identiteettinsä, joka poikkeaa varsin paljon Venäjän Euroopan-puoleisista pohjoisista alueista. Käsitteet "pohjoinen" ja "arktinen" ovatkin Venäjällä varsin erilliset. Venäjän arktisella (Russkaja Arktika) viitataan mihin hyvänsä ihmisen näkökulmasta kaukaiseen pohjoiseen ympäristöön, jossa ihminen ei yleensä ole läsnä. Venäjän Pohjola (Russki Sever) taas liittyy paitsi maantieteellisesti suppeampaan alueeseen myös läheisesti ihmiskulttuuriin. 
Venäläisinä pomorit eivät ole etninen ryhmä eivätkä edes heimo, mutta heillä on hyvin vahva oma kulttuurinen identiteettinsä (ks. Anufrijev 2013). Koska maanviljely ei karuilla pohjoisilla seuduilla ole ollut kannattavaa, pomorien elinkeinot ovat perustuneet kalastukselle ja merinisäkkäiden pyynnille (Vlasova \& Tšistov 1976, 28). Tämä riippuvaisuus merestä yhdistettynä syrjäiseen asuinalueeseen on pomori-identiteetille keskeistä. Myös kristinusko on tärkeä osa pomorikulttuuria. Venäläisen ortodoksisuuden lisäksi alueella on paljon vanhauskoisuutta. Pomorialueella ei keisarillisellakaan ajalla esiintynyt maaorjuutta, vaan vesiapajat olivat yleensä talonpoikien yhteisomistuksessa, jossa harjoitettiin kollektiivista pyyntiä (Vlasova \& Bernštam 1976, 59). Vallankumoukseen mennessä yksityisomistus oli kuitenkin yleistynyt jo niin paljon, että siirtymä kolhoositalouteen aiheutti myös pomorialueella suuren yhteiskunnallisen muutoksen, joka johti nopeasti teolliseen kalastukseen ja sitä myötä moninkertaisiksi kasvaneisiin kalastusmääriin (Brain 2018).

Šergin asemoi itsensä paitsi kirjailijaksi myös folkloristiksi, joka kirjaa ylös pomorien kansanperinnettä ja elämäntapaa. Taustalla on ajatus pomorien hyvin erityislaatuisesta kansanperinteestä, jonka kautta venäläistä sielunmaisemaa voisi ymmärtää paremmin. Näkemystä on tukenut merkittävä keskiaikaisen venäläisen kirjallisuuden historian, kulttuurihistorian ja filologian tutkija Dmitri Lihatšov (2004), johon pomorien omaleimainen kieli, laulut, tarinat ja sadut sekä "yksinkertainen ja teeskentelemätön" elämäntapa tekivät suuren vaikutuksen hänen vieraillessaan alueella ensi kertaa kesällä 1921: "minusta tuntui, että tämä on ainoa oikea tapa elää”. Uransa loppupuolella hän kuvasi pohjoisvenäläisen kulttuurin saavutuksia, mukaan lukien pohjoisen kertomus- ja lauluperinteen, "täysin ainutlaatuisiksi" sekä pohjoista aluetta "venäläisen kansankulttuurin aidoksi vaalijaksi" (Lihatšov \& Janin 1986, 115, 118).

Vaikka Šerginin kirjallinen tuotanto perustuu pomorien suulliselle kansanperinteelle ja sen kieli jäljittelee pomorialueen talonpoikaista kieltä (Horkova 2010, 160), se ei ole tarkkaa kansanperinteen dokumentointia vaan hyvin kirjallistettua sellaista. Aleksandr Pantšenkon $(2005,18)$ termein, sitä voi kutsua "folklore 2:ksi", joka "koostuu yhteiskunnan hyväksymistä teksteistä, virallisesti ja/tai sovinnaisesti kansanperinteeksi nimetyistä”. Siinä näkyy varhaiselle neuvostoajalle tyypillinen "romanttinen näkemys suullisesta perinteestä 'kansan hengen' ilmiasuna" (Arhipova \& Nekljudov, 2013, 35). Šergin kirjoittaa itsensä tähän traditioon ja sen jatkumona häntä on ollut tapana myös lukea. Tässä mielessä Šerginiä voi verrata H. C. Anderseniin, joka sanoi kirjanneensa ylös tanskalaisia kansansatuja silloinkin, kun muokkasi omia versioitaan saduista, joiden alkuperä oli epäselvä (Hafstein 2014, 9-10).

\section{Pohjoisen sakraali maantiede ja pohjoinen teksti}

Seuraavaksi esittelen näkökulmia, joiden kautta Šerginin tuotantoa on tyypillisesti aiemmin luettu. Venäläisen kirjallisuuden niin sanotun pohjoisen tekstin käsitteen taustalla on Vladimir Toporovin (2003) Tarton-Moskovan semioottisen koulukunnan hengessä vuonna 1984 esittelemä pietarilaistekstin käsite, joka viittaa kokonaisvaltaiseen ja palimpsestiseen käsitykseen siitä, mitä Pietarin kaupunki kulttuurisesti on ja miten tämä käsitys on historiallisesti muodostunut. Sittemmin tutkijat ovat tunnistaneet vastaavia tekstejä monista muista Venäjän kaupungeista ja alueista, ja pohjoinen teksti on yksi niistä. Sen taustalla on Pohjoisen (Arktisen) federaatioyliopiston etnografian, kulttuurin ja uskontotieteen tutkijan Nikolai Terebihinin (1993) esittelemä pohjoisvenäläisen sakraalin maantieteen (sakralnaja geografija Russkogo Severa) käsite. Terebihinin $(1993,4)$ luennassa pohjoisen sakraali maantiede koostuu toisaalta 
pohjoisvenäläisten maiseman ja kansojen uskonnollis-mytologisista käsityksistä sekä toisaalta sakraaleja merkityksiä saaneista konkreettisista maantieteellisistä kohteista.

2000-luvulla pohjoisvenäläiseen sakraaliin maantieteeseen liittyvässä tutkimuksessa on puhuttu pohjoisesta tekstistä. Terebihinin määritelmässä pohjoinen teksti on eräänlainen pohjoisen Venäjän henkisten tai hengellisten ja kulttuurihistoriallisten ilmiöiden kokonaisuus (Galimova 2013, 14). Semioottisen tekstikäsityksen mukaisesti se ei viittaa ainoastaan tekstiin jonakin viestin sisältävänä kirjoitettuna, vaan siihen liittyy ajatus pohjoisen niin aineellisesta kuin henkisestä kulttuurista laajemminkin. Vaikka pietarilaistekstiin ei liity vastaavia sakraaleja tai venäläismyyttisiä lähtökohtia, niin pohjoisen sakraalille maantieteelle on keskeistä ajatus siitä, että pohjoisen arvaamaton ja ankara ilmasto on tuottanut luonnolle ihmisen kannalta uskonnollisia merkityksiä. Siihen viittaa Terebihinin (1993) pohjoisen sakraalia maantiedettä esittelevän teoksen alaotsikkokin: "Pohjoisvenäläisen kulttuurin uskonnollis-myyttinen tila".

Terebihinin lisäksi pohjoista tekstiä on tutkinut erityisesti Jelena Galimova $(2013,15)$, jolle se tarkoittaa venäläiskansallisen maailmankuvan pohjoisvenäläistä muunnelmaa. Hän on selvittänyt, mikä pohjoisessa tekstissä on ainutlaatuista ja etsinyt vastauksia siihen, mitä pohjoinen teksti Venäjän pohjoista käsittelevissä kirjallisissa teoksissa on sekä millaista pohjoista tilaa Venäjän pohjoista käsittelevät tekstit yleisemmin ottaen luovat. Pohjoiseen tekstiin liittyy ajatus pyhistä ja myyttisistä merkityksistä, jotka liittävät ne sakraaliin maantieteeseen. Näiden merkitysten taustalla on venäläisen kulttuurin "pohjoisen myytti", jolle keskeistä on pohjoisen ja etelän vastakkainasettelu. Kun tässä myytissä Venäjä kokonaisuutena on asettunut vastakkaiseksi eteläiselle Euroopalle, edustaa Venäjän pohjoinen siinä erityistä venäläisyyttä (mt.). Galimovan luennassa tällaiset merkitykset sekoittuvat pohjoisessa tekstissä myös profaaneihin merkityksiin, kuten historiallisiin tapahtumiin ja jokapäiväiseen elämään.

Galimovan $(2013,16)$ mielestä pohjoinen teksti edustaa "Venäjän pohjoista mytopoeettisena tilana, sellaisena kuin se muodostuu venäläisen elämän, Venäjän historian, venäläisen kulttuurin, venäläisen henkisyyden, venäläisen sielun ja venäläisen poeettisen sanan sulatusuunissa". Tämä heijastaa ajatusta pomorialueen Pohjolan edustamasta erityisen aidosta venäläisyydestä, mikä on Venäjän pohjoisen mytopoetiikkaa hallitseva suuri kertomus. Lisäksi Galimovan $(2013,20)$ mukaan pohjoista tekstiä luovat kirjoittajat yrittävät"selvittää Venäjän pohjoisen salaisuuden". Myytit, mysteerit, salaisuudet ja hengellisyys eri muodoissaan ovat pohjoiselle tekstille keskeisiä.

\section{Pohjolan narratiivinen identiteetti}

Boris Šerginin pomorielämää kuvaavat teokset sijoittuvat Venäjän Euroopan-puoleisille pohjoisille alueille, joiden keskuspaikaksi hahmottuu Arkangelin kaupunki. Galimovan $(2013,19)$ mukaan "venäläisen kirjallisuuden pohjoisen tekstin ydin sekä sen rikkaimmat ja sisimmäiset sivut löytyvät epäilemättä Šerginin teoksista". Terebihin $(2004,1)$ taas kirjoittaa, että "Šerginin pohjoinen teksti ... on pohjoisvenäläisen kulttuurin itsetietoisuuden sekä sen perustavanlaatuisten myyttien, merkitysten ja arvojen täydellisin ruumiillistuma". Jo esitellessään pohjoisvenäläisen sakraalin maantieteen käsitteen Terebihin (1993, 11-28) pohjasi pohjoisen meren ja laivan mytologian kuvauksessaan paljolti Šerginiin. Seuraavassa tarkastelen sitä, millaisia merkityksiä Šerginin tuotannossa luonto sekä luonnon ja ihmisen keskinäisvaikutus saavat. Haen toisenlaisia, enemmän materiaaliseen kanssakäymiseen perustuvia, merkityksiä kuin pohjoisen tekstin mytopoetiikkaan ja pohjoisen "arvoituksen" selvittämiseen tähtäävät luennat, joiden kanssa kuitenkin käyn vuoropuhelua. 
Šerginin kertomuksille on ominaista, että pohjoista käsitellään nimenomaan käsitteen "Pohjoinen" (Sever) kautta. Arktista niissä ei mainita kertaakaan, ja napa-alueisiinkin viitataan vain muutaman kerran naparetkeilijöiden ja kaamoksen yhteydessä. Tämä on luontevaa, sillä kyseessä on ihmisen läsnäoloon perustuva ajatus pohjoisesta. Šerginin Pohjoinen kirjoitetaan yleensä isolla alkukirjaimella, ja "Pohjola" onkin sille ehkä osuvin suomennos. Pieni alkukirjain esiintyy vain tilanteissa, joissa pohjoiseen liitetään jotain erikoismerkityksiä. Sama pätee Šerginin tuotantoa pohjoisena tekstinä käsittelevään tutkimuskirjallisuuteen, joka tältä osin jakaa sen kanssa saman semiosfäärin.

Narratiivinen identiteetti on käsite, joka viittaa paitsi yksilön itselleen tarinallistamaan identiteettiin, myös yhteisöjen tapaan rakentaa tilallista identiteettiään kertomusten kautta (Ridanpää 2017, 262). Narratiivisesti syntyvät alueelliset identiteetit saavat vaikutteita muun muassa luonto- ja maisemakäsityksistä, kulttuurista ja etnisyydestä, murteista, talouselämästä, asemasta keskuksessa tai periferiassa sekä "meidän" ja "muiden" vastakkainasetteluista (Paasi 2003, 477). Kuten Ridanpää $(2017,257)$ toteaa, kirjailijoilla on usein ajateltu olleen erityinen taito tunnistaa ja eritellä näitä alueellisen identiteetin tekijöitä sekä muodostaa niistä kokonaiskuva. Tällainen taito on pohjoisen tekstin osalta katsottu olleen erityisesti Šrerginillä, jolla Terebihin $(2004,141)$ kuvaa olleen "jumalallinen selvänäköisyyden ja mystisen intuition lahja".

Koska Šerginin tuotanto on keskeisesti määrittänyt sitä, mitä pohjoisella tekstillä ymmärretään, se on keskeinen myös pohjoisvenäläisen kollektiivisen identiteetin kannalta. Šerginin tuotanto yhdessä sitä pohjoisen tekstin arkkityyppinä tulkitsevien luentojen kanssa luo pomorialueen kuvitteellista maantiedettä (vrt. Said 2011, 55-76) ja sitä kautta sen alueellista narratiivista identiteettiä. Tarkastelen Šerginin tuotannon välittämiä käsityksiä siitä, mitä "pohjoinen" merkitsee ja minkälaista narratiivista pohjoisvenäläistä (pomori)-identiteettiä se rakentaa. Peilaan analyysiäni siihen, mitä venäläinen pohjoista tekstiä tutkiva kirjallisuudentutkimus on Šerginin pohjoisen käsityksistä sanonut sekä siihen, mikä on tämän tutkimuksen merkitys narratiivisen pohjoisvenäläisen identiteetin kannalta.

Ominaista Šerginin pohjoisen kuvaukselle on, että se näyttäytyy yhtä aikaa niin rikkaana kuin köyhänäkin. Tälle pohjoiselle identiteetille on oleellista se, että elämän edellytykset eivät "pohjoisen ankarassa ilmastossa" ole kummoiset (OMR, 138). Maan köyhyys näkyy myös taiteen tuottamisen edellytyksissä, sillä eräs Šerginin kertoja kuvaa miten hänen on kuvataiteessaan pitänyt käyttää männystä, kuusesta ja lepästä valmistettuja maalaustarvikkeita, sillä "lehmusta ei Pohjoisessa ole" (OMR, 106). Elinkeino perustuu kalastukseen, sillä pohjoinen "maa ei leipää synnytä" (GSM, 150). Vienanmeren ja Pohjoisen jäämeren kalastus onkin jo 1800-luvun jälkipuoliskolla noussut Venäjän kalanpyynnissä toiseksi suurimmaksi, ja kalaa on pyydetty paitsi omaan tarpeeseen myös viljan ja muiden tavaroiden vaihtoa varten (Bernštam 1976, 92).

Niukoista edellytyksistä huolimatta elämä pohjoisessa näyttäytyy rikkaana. Materiaalista varakkuutta kuvaa vuonna 1939 ilmestynyt kertomus "U korabelnogo pristaništša" ("Laivojen tyyssijan tykönä"), joka nostaa esiin myös muut kuin meren antimet: "Yltäkylläinen on Vienanmaa! Se on rikas kalasta ja villieläimistä sekä karjasta, ja metsästä vielä monin verroin enemmän!” (UPR, 10). Villieläimet, eli mursut, majavat ja soopelit, oli tosin jo 1800-luvulla metsästetty pomorialueella mantereelta sukupuuttoon (Bernštam 1976, 100). Šrginin tuotannossa se, että ilman tätä liikametsästystä elämä voisi olla vielä rikkaampaa, ei tule mitenkään esiin. Metsästysretket siinä kyllä suuntautuvat aina pitkien ja vaarallisten merimatkojen päähän, erityisesti Novaja Zemljalle. Vuonna 1959 ensi kerran ilmestyneessä 
kertomuksessa "Staryje staruhi" ("Vanhat mummot") taas pohjoinen on paikka, jossa "on tapana elää vanhaksi" vaikka iänikuisen nauriin puremisen sijaan tekeekin mieli "omenien perässä eteläisiin maihin" (OMR, 156, 162). ${ }^{3}$ Pohjoinen tila asettuu ahtaan kaupunkitilan vastakohdaksi: "Tottuneena rajattomiin pohjoisiin valoisiin lakeuksiin jouduin ahtaisiin kaupunkeihin" (UPR, 15). Tämä kaupunkitilan vastakohtaisuus on pohjoiselle tilalle tyypillistä muissakin kulttuureissa, mukaan lukien suomalaisessa. Neuvostoliiton aikana Venäjän pohjoisille alueille perustettiin monia kaupunkeja ja niihin muutti paljon työväkeä (ks. Bolotova 2014, 54-72). Tämän vuoksi pohjoinen ja urbaani eivät Venäjällä välttämättä ole toisiaan poissulkevia tiloja. Šerginin tuotannossa ne eivät kuitenkaan yhdisty.

Šerginin Pohjola tarkoittaa tyypillisesti paikkaa, jolle meri, laivanrakennus ja merenkulku ovat keskeisiä. Šerginin pohjoisessa tekstissä meren asema korostuu. Terebihinin $(2004,1)$ mukaan meren mytologiset merkitykset ovat siinä niin keskeisiä, että sitä voisi pikemminkin kutsua pohjoisvenäläisen meren tekstiksi (severomorski tekst). Terebihinin (mt., 141) mukaan Šergin oli ensimmäisiä, joka liitti venäläisen sielunmaiseman metsän tai aron sijaan ensisijaisesti mereen. Myös Galimovan $(2013,48)$ luennassa meri niin Šerginillä kuin pohjoisessa tekstissä yleisemminkin liittyy elämän ja kuoleman kysymyksiin, pomorien maailmankatsomukseen ja ihmisenä olemiseen. Galimova nostaa Šerginin tuotannosta lukuisia esimerkkejä, joissa meren mytopoeettiset merkitykset pomorielämän keskiössä nousevat esiin. Nämä ovat keinoja, joilla Šerginin tuotanto luo sellaista narratiivista pomori-identiteettiä, joka perustuu elämälle meren äärellä ja sen ehdoilla. Laivat ja niiden rakentajien taidot korostuvat pohjoisen tekstin tutkimuksessa. Itse meri jää vähemmälle huomiolle, mikä kuvastaa tutkimuksen antroposentristä luonnetta.

Paitsi pohjoisen tekstin tutkijoiden kirjaamia mytologisia merkityksiä, Šerginin tuotanto korostaa merta myös arkisemmissa merkityksissä. Monien hänen kirjojensa lopussa on sanasto, joka avaa paikallista kieltä. Nämä sanastot heijastavat hyvin ajatusta Pohjoisesta laivanrakennuksen ja merenkulun paikkana. Niissä selitetään lukuisia Šerginin teoksissa esiintyviä pohjoiseen merenkulkuun ja laivanrakennukseen liittyviä termejä, esimerkiksi pomorien erityyppisistä laivoista käyttämiä nimiä. Monessa tarinassa mainitaan "ikivanha pohjoinen merenkulku" (Zapetšatlennaja slava, ZS, 15), "pohjoisvenäläinen ammattimainen ${ }^{4}$ merenkulku" (ZS, 360) tai "pohjoiset merenkävijät" (GSM, 123). Toistuva käsite on myös "pohjoinen 'merentuntemus"' (GSM, 40). Tässä esiintyvää käsitettä znanije käytetään niin, että se viittaa merenkulkutaitoihin myös silloin, kun merta ei erikseen mainita. Se kuvastaa meren roolia pomorien elämän keskeisimpänä luonnon elementtinä:

\footnotetext{
Merenkulku Vienanmerellä ja Pohjoisella Jäämerellä sekä niiden lahdissa vaati valtavasti kokemusta ja tietoa. Oppia laivan ohjaamisesta näiden merten eri osissa pomorit ovat kutsuneet 'tuntemukseksi'. Erikseen on puhuttu Novaja Zemljan tuntemuksesta - taito ohjata laivaa Novaja Zemljan länsirannikolla - sekä Vienanjoen ja Solovetskin tuntemuksesta, jolla viitataan alusten ohjaamiseen Vienanjoen vaativilla väylillä lukuisten saarten ja saariryhmien keskellä. (ZS, 71.)
}

Paitsi merenkulkualue, Šerginin Pohjola on myös ikivanha asuinpaikka ja alue, jossa bylinaperinteen runoelmat elivät pitempään kuin missään muualla (GSM, 131). Pohjoisen keskiaikaisten asukkaiden vihollisia olivat jokia pitkin alueelle tunkeutuneet novgorodilaiset "uškuinikit" (OMR, 343) sekä nykyisen Suomen alueelta hyökänneet ruotsalaiset "kajaanit" (ZS, 193). 1600-luvulla tsaari Aleksein vainon aikana, se oli skomorohien, alempiluokkaisten 
laulajien ja ilveilijöiden, turvapaikka (ZS, 323). Venäjän pohjoinen on vanhauskoisten vahvimpia alueita ja myös sen lähtökohtana ovat 1600-luvun vainot. Šergin ei kuitenkaan yhdistä tätä historiallista taustaa Pohjolan käsitteeseen, vaikka hänen myöhäiskauden tuotannossaan kristinusko siihen tiiviisti liittyykin. Pohjois-Venäjä oli joka tapauksessa suhteellisen eristäytyneisyytensä ansiosta hyvä turvapaikka keskushallinnon epäsuosioon joutuneille. Tämä eristäytyneisyys oli yksi syy siihen, että pomoreille kehittyi niin omaleimainen kulttuuri (Brain 2018, 190). Muita syitä olivat merestä riippuvainen elinkeino sekä slaavien rinnakkaiselo ja sekoittuminen pohjoisen etnisten ryhmien kanssa, kuten karjalaisten, komien, nenetsien ja saamelaisten (Vlasova ja Tšistov 1976, 28). Epäilemättä myös keskusvaltaa paennut väestö omalta osaltaan vaikutti tähän omaleimaisuuteen.

Vaikka Šerginin Pohjola on pomorien vanha asuinpaikka, niin modernisaatio on senkin saavuttanut. Pohjoisen modernit piirteet eivät kuitenkaan ole ristiriidassa perinteisen elämäntavan kanssa, vaan täydentävät sitä. Vuonna 1957 ensimmäisen kerran ilmestynyt kertomus "Kak Fedosja Nikitišna u Lenina byla" ("Kun Fedosja Nikitišna Leninin luona kävi") viittaa vuonna 1928 Arkangelin ja Leningradin välisellä, hieman aiemmin avatulla "Pohjoisella rautatiellä" käytyyn keskusteluun, joka käsitteli erään pomorimuorin vierailua Pietarin Smolnassa pian vallankumouksen jälkeen (OMR, 244). Kertomuksesta saa sen vaikutelman, että rautatieyhteyden kautta pomorialueiden yhteydet neuvostovaltion keskukseen olivat hyvät jo 1920-luvulla. Rautateiden rakentaminen kaukaisiin pohjoisiin osiin oli osa neuvostovaltion arktisten alueiden niin sanottua normalisaatiota, jonka tavoitteena oli levittää neuvostotila valtakunnan joka kolkkaan (ks. Frank 2010, 117). Hyvät rautatieyhteydet eivät näytä olevan ristiriidassa Šerginin tuotannon välittämään ajatukseen pohjoisesta vanhana ja eristäytyneenä asuinalueena, jossa muinainen runonlaulukin elää vielä neuvostoajan alkuvuosina.

Šerginin pohjoinen luonto on erityinen. Se näkyy revontulten ja "auringonlaskuttomaksi päiväksi" (OMR, 426) kutsuttujen valoisten kesäöiden lisäksi siinä, miten luontoelementteihin liittyy attribuutti "pohjoinen". Hilla on "pohjoinen marja" ja tylli on "pohjoinen lintu" (UPR, 29). Molempia kyllä esiintyy muuallakin, mutta ne esitetään nimenomaan (Venäjän) pohjoiselle tyypillisinä, sitä määrittävinä lajeina ja ovat siten osa pohjoista narratiivista identiteettiä. Erityisesti linnut saavat pohjoisuuteen liittyviä merkityksiä, jotka yhdistävät ne usein ihmisiin. "Muurmannin tylleiksi" kutsutaan poikia, jotka noin kymmenvuotiaina lähtevät tutustumaan merenkulun saloihin pitkille pyyntimatkoille Muurmannille (UPR, 29-39). Bernštam (1976, 98) mainitsee, että merelle mukaan otettuja poikia on ollut tapana kutsua myös "silakanpoikasiksi" (salažonok). Tarinan "Dlja uveselenja" ("Huviksi") päähenkilöt, kalastajaveljekset Ivan ja Ondrejan taas "kiertelivät saarensa ympärillä kuin haahkat" leivässä pysyäkseen (OMR, 111).

Myös arktiset nisäkkäät, jääkarhut, naalit ja mursut, ovat keskeinen Pohjolaa määrittävä piirre. Yleensä niillä ei tosin ole sen kummempaa roolia kuin olla metsästettävinä. Kuukausien mittaiset metsästysmatkat määrittävät suurelta osin pomorien elämänrytmiä. Paitsi pitkillä metsästysretkillä, myös mantereella eläinten käyttäytymisen tunteminen on Šerginin kuvaaman pomorielämän elinehto: vuonna 1939 ilmestyneessä kertomuksessa "Murmanskije zuiki" ("Muurmannin tyllit") kuvataan, miten ihminen voi kahdesti käydä ryöstämässä kuikan pesänsä pehmikkeeksi keräämät höyhenet, mutta jos sen tekee kolmannen kerran, lintu lentää pois eikä koskaan enää palaa (UPR, 38).

Sääoloista pakkanen ei niinkään määrittele Šerginin Pohjoista kuin tuuli, jonka suunnat ja muut ominaisuudet määräävät ihmiselämää ja joka "ei koskaan nuku" (OMR, 327). Tuulet ovat merkityksellisiä myös pohjoisen sakraalissa maantieteessä (Terebihin 1993, 14). Koska 
tuulten on ajateltu kuljettavan henkiä mukanaan, erilaisille tuulille on annettu omat nimensä ja tarinansa (Brain 2018, 194). Šerginin kertomuksissa kevättuuli puhaltaa etelästä ja on ihmisille hyödyllinen, koska se vie jäät kauas pohjoiseen (ZS, 75-76). Kesätuuli taas on "hento ja hyväntuoksuinen tuulonen" (OMR, 21), mutta syksyllä alkaa puhaltaa "koillistuuli, joka muuttaa sateen lumeksi” (OMR, 23). Tämän Jäämereltä koillisesta puhaltavan tuulen nimi on polunotšnik, missä "pohjoisen" korvaa sana "keskiyö". Keskiyö on vanha pohjoisen synonyymi, sillä keskiyöllä aurinko on pohjoisessa. ${ }^{5}$

Šrginin koillistuuli on pelottava, koska sen mukana irtojäät palaavat pohjoisesta ihmisalueille ja merenkulku käy vaaralliseksi. Koillistuulen nostama aallokko "hallitsee" koko Vienanmerta (ZS, 264). Vaikka Terebihin $(1993,14)$ kuvaa koillistuulta "kohtalon tuuleksi", aina ei Šerginin koillistuuli kuitenkaan ole haitallinen, vaan jotain, jonka kanssa on totuttu tulemaan toimeen. Tarinassa "Novozemelskoje znanije" ("Novaja Zemljan tuntemus") rannalta idästä nouseva tuuli aiheuttaa "hirvittävän huonon sään" ja eristää metsästysretkellä olleet kaksi laivaa toisistaan (OMR, 59-62). Itätuuli muuttuu etelätuuleksi, jota kutsutaan "venäläiseksi tuuleksi” - nähtävästi siksi, että se puhaltaa mantereen suunnalta. Venäläinen tuuli pitää laivat erossa päiväkausia, mutta kun tuuli kääntyy koilliseksi, pääsevät laivat matkaan ja kapteeniensa erinomaisen merenkulkutaidon ansiosta löytävät toisensa. Koillistuulesta on hyötyä myös sumussa, koska keväällä ja kesällä se hajottaa sumun (ZS, 264, 266).

Terebihin $(2004,1)$ luonnehtii Šerginia "Pohjoisen rukouskirjaksi ja askeetiksi, sen ikuisten satujen ja salaisuuksien luojaksi ja vaalijaksi" sekä "Pohjoisen runoilijaksi, myytinluojaksi ja filosofiksi". Sanat "luoja" (tvorets) ja "myytinluoja" (mifotvorets) ovat tässä tärkeät - ne viittaavat siihen, että Šergin ei ainoastaan toisintanut pohjoista koskevaa mytologiaa vaan myös kehitti sitä. Näillä keinoin hän, Terebihinin (mt.) sanoin, "ikuisti ... Pohjois-Venäjän idean sekä määritteli pomorialueen paikan venäläisen maailman tilassa". Pohjoisen myyttiset merkitykset avautuvat paitsi Šerginin tuotantoa analysoimalla myös sitä pohjoisen tekstin arkkityyppinä tulkitsevaa tutkimuskirjallisuutta tarkastelemalla. Yhdessä nämä rakentavat pohjoisvenäläistä narratiivista identiteettiä.

Sakraalin maantieteen ja pohjoisen tekstin tutkimuksen ansio on siinä, että se tarkastelee Venäjän Pohjolaa sellaisena kuin se näyttäytyy sisäpuolelta. Näin se välttyy ulkopuoliseen katseeseen usein liittyvältä pohjoista toiseuttavalta sekä siihen alentuvasti ja eksotisoivasti suhtautuvalta arktisismilta (ks. Ryall, Schimanski \& Wærp 2010, x). Toisaalta se kirjoittaa itsensä mukaan pohjoisen tekstin diskurssiin eikä kiinnitä huomiota sellaisiin Pohjois-Venäjään liittyviin merkityksiin, jotka eivät kanonisoidussa kirjallisuudessa Venäjän pohjoisesta esiinny. Šergin esimerkiksi kirjoittaa usein Solovetskin saaresta, mutta aina vain siellä ennen neuvostoaikaa sijainneen luostarin ja siihen liittyvien hengellisten merkitysten kautta. Solovetskilla oli kuitenkin myös 1920-1930-luvulla suuri, Neuvostoliiton ensimmäinen poliittisille vangeille tarkoitettu pakkotyöleiri, jota Aleksandr Solženitsyn $(1976,111)$ kutsui gulagien "alma materiksi". Siitä Šergin ei kuitenkaan lainkaan kirjoita, ja leiri on rajattu myös pohjoisen tekstin tutkimuksen ulkopuolelle. Näin jää epäselväksi, mikä on ollut leirin merkitys pohjoisen alueelliselle identiteetille sekä siihen, millaisia käsityksiä pohjoisesta on historiallisesti muodostunut.

Marina Nikitina $(2018,26)$ toteaa, että Šerginin päiväkirjoissa Venäjän pohjoinen näyttäytyy "epätavallisena, satumaisena tilana", josta hän "löytää mielenrauhan". Pohjoinen on niissä eräänlainen ikuisuuden tilallinen vastine, jossa luostarien läheisyys luo turvaa maalliselle elämälle (mt., 27). Pohjoinen luonto on päiväkirjoissa elollinen ja henkevä, ja meri on tärkein pohjoista tilaa järjestävä elementti (mt., 30). Päiväkirjoista välittyy hyvin samanlainen 
mytopoeettinen käsitys pohjoisesta kuin siinä pohjoisen narratiivisessa identiteetissä, jota Šerginin kaunokirjallisuus luo ja jota pohjoisen tekstin tutkimus vahvistaa.

\section{Kristinuskon yhteydet ympäristön hyväksikäyttöön}

Kun akateemikko Dmitri Lihatšov teinipoikana kävi Venäjän pohjoisessa, hän koki nähneensä "Pyhän Venäjän" aidoimmillaan ja ihailtavimmillaan (Zubok 2017, 13). Myöhemmin Lihatšov (2004) kirjoitti Venäjän pohjoisesta: 'Ihmiset tulevat tänne niin nyt kuin tulevaisuudessakin kokeakseen pohjoisen parantavan moraalisen voiman." Venäläisen kirjallisuuden pohjoisen tekstin esityksissä näkyy myös eetos pohjoisesta elämästä moraalisesti esimerkillisenä. Galimova $(2013,33)$ mainitsee Šerginin pohjoisen tekstin keskeiseksi funktioksi pomorielämän perinteiden säilyttämisen, mukaan lukien henkisten ja moraalisten. Kirjailija Juri Galkin on kuvannut, että Šerginin tunnetun kertomuksen "Dlja uveselenja" päähenkilöiden elämänkatsomus perustuu eläimellisten vaistojen sijaan inhimillisille moraalisäännöille (Galimova 2013, 37). Kertomuksessa "Vanka Dobroi” ("Hyvä Vanja", 1936) taas Venäjän pohjoinen ja sen moraalille perustuva yksinkertainen elämä esiintyvät syntisen Pariisin vastakohtana. Seuraavassa avaan tarkemmin sitä, minkälaiselle moraalikäsitykselle Šerginin pohjoisen tekstin luontosuhde perustuu.

Ortodoksinen kristillisyys on keskeinen osa pohjoisen tekstin käsitettä, koska sen pohjalla on pohjoisen sakraali maantiede ja siihen liittyvät pyhinä pidetyt ja myyttiset käsitykset. Kiintoisa kysymys on, onko kristillisellä tai ortodoksisella etiikalla jotain tekemistä sen kanssa, miten Venäjän pohjoisen väestö on suhtautunut ei-inhimilliseen ympäristöönsä. Pomorien uskonnollisiin näkemyksiin ovat vaikuttaneet vanhauskoisuus ja animistiset uskomukset, jotka ovat eläneet rinnan isovenäläisen ortodoksisuuden kanssa.

Stephen Brain on sitä mieltä, että pomorien sakraaliin maantieteeseen pohjaava elämäntapa yhdessä heidän uskonnollisten katsomustensa kanssa ovat johtaneet heidän ympäristön kannalta eettiseen talouselämäänsä, jota Brain $(2018,190)$ kutsuu "moraaliseksi". Kristinuskon antroposentrisyyden on usein nähty olevan länsimaisen kulttuurin kestämättömän ympäristösuhteen taustalla, ja globaalin ekologisen kriisin juurisyyksi on nähty länsimaisen kulttuurin usko ikuiseen kehitykseen. Lynn Whiten $(1967,1205)$ mukaan tämä niin antiikin Kreikalle ja Roomalle kuin itämaisille kulttuureille ja animismille vieras ajattelutapa kumpuaa juutalais-kristillisestä teleologiasta, jossa se on keskeinen. Tämä näkyy jo siinä, miten Jumala antaa Vanhan testamentin luomiskertomuksessa kaikki muut lajit ihmisen hallittaviksi valtuuttaen hänet ottamaan ne valtaansa sekä kehottaa ihmistä lisääntymään ja täyttämään maan (1. Moos 1:26-29).

Whiten vaikutusvaltainen artikkeli ilmestyi jo 1960-luvulla, ja sitä on kritisoitu paljon muun muassa ekoteologian piirissä. Esimerkiksi Timothy Weiskel(1997) on kerännyt Whiten kanssa keskustelevien artikkelien luettelon. Kysymys juutalais-kristillisen perinteen vaikutuksesta ympäristön hyväksikäyttöön on epäilemättä Whiten esittämää monimutkaisempi. Hänen kriitikkonsa yleensä joko pitävät hänen näkemyksiään idän ja lännen eroista liian yleistävinä tai syyttävät häntä Raamatun tarkoituksellisesta väärintulkinnasta. Brain (2018, 192) menee kuitenkin pidemmälle, sillä hänen mukaansa pomorien elämäntapa ei ole perustunut eettisesti kestävälle ympäristösuhteelle ainoastaan kristinuskosta huolimatta, vaan jopa nimenomaan sen vuoksi. Tämä suhde katkesi vasta 1930-luvulla Stalinin käynnistämän talouden modernisaation myötä. Brainin näkemystä kritisoi pomorien kalatalouden historiaa tutkinut Julia Lajus (2018, 219), jonka mukaan pomorikulttuurin vähäisen ympäristökuormi- 
tuksen syynä ei ole ollut ympäristötietoisuus sellaisena kuin se nykyään ymmärretään, vaan harva asukastiheys, perinteinen seuraelämä ja kehittymätön teknologia.

Oli syy missä hyvänsä, joka tapauksessa 1930-luvulle asti ei-inhimillisen luonnon hyväksikäyttö Venäjän pohjoisessa oli suhteellisen vähäistä moneen muuhun paikkaan verrattuna. Tutkimalla pohjoisen tekstin kirjallisuutta ei ole mahdollista vahvistaa sitä, missä määrin pomorien uskonnolliset katsomukset olivat tämän taustalla, sillä koko pohjoisen tekstin käsite on osa tätä katsomusjärjestelmää eikä sitä voi pitää luotettavana lähteenä tämän kysymyksen kannalta. Sitä tutkimalla voi kuitenkin selvittää, millä lailla pomorien uskomusjärjestelmä on saattanut heidän luontosuhteeseensa vaikuttaa. Šerginin kohdalla kristilliset motiivit ovat huomattavan vähissä 1960-luvulle asti, mutta hänen kahdessa viimeisessä kokoelmassaan ensimmäistä kertaa julkaistuille kertomuksille ne ovat tyypillisiä. Seuraavassa tarkastelen kristillisen moraalin liittymistä luontoyhteyteen täysin vastakkaisesti kahdessa kokoelman Zapetšatlennaja slava ("Ikuistettu kunnia", 1967) kertomuksessa.

Kertomuksen "Krotkaja voda" ("Laskuvesi") alussa kertoja kerskailee kotikylänsä Nenoksan asukkaiden luonnonvoimien tuntemuksella: "tunnemme tuulen ja veden sekä kaikki meren oikut" (ZS, 177). Se ei kuitenkaan hänelle riitä, vaan hän hakee vaikealle merimatkalle lähtiessään myös Pyhän Nikolauksen suojelua. Pyhä Nikolaus on merenkävijöiden suojelupyhimys, joka on pomorien käsitysmaailmassa erityisasemassa ja rinnastuu usein Kristukseen (Terebihin 1993, 17). Pyhän Nikolauksen kautta on siten ajateltu saatavan suora yhteys Kristukseen, kun muut pyhimykset toimivat vain sanansaattajina. Rukouksista huolimatta kertojan laiva haaksirikkoutuu ja henkiin jää vain muutama, jotka saavat suojaa aution saaren tsasounasta ja lohtua sen ikoneista. Viimein eloonjääneet pelastetaan ja heidät viedään lähimpään kylään, jossa juhlitaan helluntaita, Pyhän Kolminaisuuden päivää. On selvää, että kertomus yhdistää pohjoista merenkulkua kristilliseen pelastusoppiin ja kuuluu siten pohjoisen sakraalin maantieteen perinteeseen. Sen voi nähdä myös tukevan ajatusta maltillisesta luonnonvarojen käytöstä, sillä Kristukseen ja kolminaisuuteen viittaamisen kautta yksi sen opetus on, että ihminen ei voi hallita luonnonvoimia, ei edes kristinuskon korkeimpien voimien avulla.

Kertomus "Sofija Novgorodskaja" ("Sofia Novgorodilainen") viittaa pomoritaruun, jonka mukaan novgorodilainen purjehtija Ivan Gostev oli ensimmäinen näille pohjoisille rannoille saapunut ja sinne mökkinsä pystyttänyt. Hän kalasti pohjoisilla vesillä ja myi saalistaan Novgorodissa, jossa käydessään rukoili Pyhän Sofian katedraalissa. ${ }^{6}$ Purjehdittuaan jo vuosikymmeniä vanha ja väsynyt Ivan pohtii, eikö leipänsä voisi ansaita lähempääkin kalastamalla kuin maailman pohjoisista ääristä. Silloin hänelle ilmestyy nainen, joka esittäytyy Jumalan Viisaudeksi, Sofia Novgorodilaiseksi. Sofia neuvoo: "Lasken merimatkojesi virstat. Oi merenkävijä! ${ }^{7}$ Kaikki virstasi lasketaan ja kaikki väkesi matkat kirjataan Novgorodin elämän kirjaan.” (ZS, 244) Niinpä Ivan päättää, että hänen pitääkin purjehtia yhä kauemmas, yhä uusille tuntemattomille rannoille. Kertomusta on pidetty yhtenä pohjoisen sakraalin maantieteen keskeisimmistä, sillä sen sanoma on, että jumalallinen kaitselmus ohjaa viisaaseen merenkulkuun ja elämään pohjoisessa (Meljutina, Popova \& Terebihin 2016, 207). Kertomuksen perusteella "viisas" näyttää kuitenkin tässä viittaavan kasvavaan luonnonvarojen hyväksikäyttöön, sillä Sofian ilmestys sai Ivanin luopumaan suunnitelmastaan rajoittaa pohjoisen luonnon kustannuksella tekemäänsä kaupankäyntiä ja päinvastoin lisäämään sitä. Tässä mielessä se näyttääkin kuuluvan samaan traditioon kuin jo Whiten (1967) kritisoima juutalais-kristillisen teleologian ikuisen kehityksen ideaali, eikä se siten istu ajatukseen pomorien hengellisen perinteen ympäristötietoisuudesta. 


\section{Arktinen neuvostomoderniteetti}

Šerginin tuotanto osuu Neuvostoliiton nopean modernisoinnin aikakaudelle. Se alkoi heti 1920-luvun alussa, kun bolševikit saivat valtansa vakiinnutettua. Kuuluisa on Leninin (1970) puhe Moskovan kuvernementin marraskuun 1920 puoluekokouksessa, jossa hän julisti: "Kommunismi on neuvostovalta plus koko maan sähköistäminen, sillä teollisuutta ei voi kehittää ilman sähköistämistä.” Modernisointiprojekti kiihtyi erityisesti ensimmäisen viisivuotissuunnitelman käynnistyttyä vuonna 1928. Luonnonvarat nähtiin ehtymättömänä resurssina, joka tulee valjastaa neuvostovaltion hyötykäyttöön. Tämä johti jyrkkään luonnon ja kulttuurin vastakkainasetteluun, jossa villi luonto oli ihmisen vihollinen. Maksim Gorkin $(1931$; 1933) mukaan ihmisen tuli taistella luontoa vastaan ja luoda ihmiskulttuurista "toinen luonto", joka olisi alistanut "ensimmäisen luonnon" täysin valtaansa. Koulukirjoista lapset oppivat miten käydä "sotaa jokea vastaan" tai "vangita kevättulvat" (Ilin 1931). 1930-luvun alkuun sijoittuu myös Neuvostoliiton arktisen tilan liittäminen modernisaatioprojektiin, niin kutsuttu "Pohjoisen hallinta" (osvojenije Severa). ${ }^{8}$ Sen tavoitteena oli normalisoida arktiset alueet eli voittaa niiden vaikeiden luonnonolosuhteiden aiheuttamat modernisaation esteet ja liittää ne yhteiseen neuvostotilaan muun valtakunnan kanssa (Frank 2010, 117).

Seuraavassa tarkastelen Šerginin tuotannon suhdetta näihin neuvostoliittolaisiin arktisiin moderniteetteihin (vrt. Frank 2017). Teema tulee esiin vuonna 1939 ilmestyneessä kokoelmassa U pesennyh rek. Sen kertomus "Stalinin perustuslaki" ylistää sitä, miten neuvostovalta ja vuoden 1936 perustuslaki takaavat luonnonvarojen hyödyttävän koko kansaa: "Vuoristomaat ja arot, joet, järvet ja purotkin, nuotat ja kalapaikat, niityt, metsät, kyntömaat, merieläinten pyynti ja kaikenlaiset tilukset - se kaikki on annettu työväestölle ikuisiksi ajoiksi ja kokonaan." (UPR, 121). Näin suorastaan naiivin antroposentrinen maailmankuva istuu täysin 1930-luvun luonnon alistamisen henkeen. Kirjailijan pyrkimys näyttää olevan säilyttää varhaisemman tuotantonsa leimallinen pomorikieli, mutta sen valjastaminen modernisaatioprojektin tarpeisiin vaikuttaa kömpelöltä. Kuten eräs tutkija toteaa: "Se [kieli] lipsahti hänen käsistään eikä suostunut hyväksymään valetta niin, että käsiin jäi vain kuolleita ja kuivia akanoita" (Novikov 2008, 63).

Saman kokoelman ensimmäinen kertomus "U korabelnogo pristaništša” on yksi Šerginin tunnetuimmista, ja se on keskeisesti määrittänyt pohjoisen tekstin käsitettä. Kertomus alkaa elegisellä kuvauksella vuodenkierrosta kertojan "avaralla ja ihanalla" kotiseudulla, jonka pohjoisuutta ja merellisyyttä korostetaan monin tavoin (UKP, 7). Se kertoo niin syksyisten vesien vaarallisuudesta kuin kesän kukkeudestakin, ja siitä piirtyy kuva ankarasta mutta arvokkaasta elämästä luonnonvoimien ehdoilla kukoistavassa ja merenkulusta riippuvaisessa maaseutukaupungissa.

Loppua kohti kertomus muuttuu kuitenkin ajan hengen mukaiseksi, sillä neuvostovalta on saapunut etäiseen pohjoiseen ja liittänyt sen tiiviiseen yhteyteen muun maailman kanssa:

Kotikaupunkini, kotiseutuni, olet ovi, portti tuntemattomille napamaille. Tutkijoita saapuu Arkangeliin kartoittamaan Pohjoisen jäämeren syvyyksiä ja etäisyyksiä. Arkangelin laitureilta lähtee jatkuvasti laivoja ympäri maailmaa. Länteen: Norjaan, Ruotsiin, Tanskaan, Saksaan, Englantiin ja Amerikkaan, pohjoiseen: Novaja Zemljalle, Huippuvuorille, Frans Joosefin maalle. Meidän päiviemme kansanvalta on avannut portit myös itään, osoittanut suunnan kohti Suurta Pohjoisväylää. Neuvostojen valta on varustanut laivat sellaisille merimatkoille, joista aiemmin vain haaveiltiin. Neuvostojen vallan uteliaat silmät ovat 
löytäneet ja varmoin askelin nousseet rannoille, maille ja saarille, joilla ei ole lokki lennellyt eikä pallaskala poikennut. Neuvostovalta on herättänyt jääkarhut, hylkeet ja mursut, reipastuttanut laiskoja ja nostanut jaloilleen uneliaat. (UKP, 15.)

Kertomuksen loppu jatkaa arktisen tilan neuvostonormalisoinnin hengessä. Se tunnelmoi runollisesti satamassa pyörivien alusten moninaisuudella, kauppaa käyvän vesiliikenteen vilkkaudella sekä matkustajia kylien ja kaupungin välillä kuljettavien höyrylaivojen runsaudella. Luonnolle se antaa puhtaasti instrumentaalisen arvon. Se ihastelee rannoille perustettuja sahoja ja niille saapuvia ulkomaalaisia, jotka vievät maailmalle "maailman parhaasta männystä" tehtyä tukkia ja lautaa "lukemattomiin tarpeisiin" (UPR, 16). Jäämerta se kutsuu "valtamerielättäjäksi", joka kasvattaa ihmisille kalaa, hylkeenrasvaa ja mursunnahkaa "suurta voittoa" tuottaen (mt.). Sen mukaan "niin turkiseläimet, linnut sekä meri- ja jokikalat, puutavara, hamppu ja pihka kuin ihrakin, se kaikki on meidän elinkeinomme, meidän tuottojamme" (UPR, 17).

Myöhemmin Šergin päivitti kertomusta, ja vuonna 1947 ilmestyneessä kokoelmassa se julkaistiin nimellä "Dvinskaja zemlja" ("Vienanmaa"). Se kuuluu jokaiseen tuon jälkeen ilmestyneeseen Šerginin kokoelmaan, mutta siitäkin esiintyy kahta erilaista versiota. Vuosina 1957 ja 1971 ilmestyneet versiot ovat keskenään samat, kuten myös vuosina 1959 ja 1967 ilmestyneet. Voisi olettaa, että antroposentrisimmat ja luonnon instrumentaalista arvoa korostavat kohdat olisi Stalinin ajan jälkeen ilmestyneistä versioista karsittu. Kertomuksen loppua ei ole kuitenkaan uudistettu täysin. Neuvostovaltaa ihannoivasta kappaleesta on poistunut vain epäselvä viimeinen lause: "Neuvostovalta on herättänyt jääkarhut, hylkeet ja mursut, reipastuttanut laiskoja ja nostanut jaloilleen uneliaat". Lisäksi vuoden 1971 versiossa ei neuvostovalta enää lähetä pohjoiseen vain laivoja vaan myös lentokoneita, eikä se enää astu ainoastaan ennestään tuntemattomille pohjoisille saarille ja rannoille vaan aina pohjoisnavalle asti (GSM, 18).

Kuitenkin kertomuksen viimeisten kappaleiden sahojen ja ulkomaalaisten ihastelu sekä luonnon kutsuminen "meidän tuotoksemme" on kaikista vuotta 1939 myöhemmistä versioista pudonnut pois. Neuvostovaltion pohjoisen hallinta siis säilyy kertomuksessa loppuun asti, mutta luonnon arvo vain ihmiselle hyödyllisenä välineenä poistuu. Sen sijaan vuoden 1957 versiosta alkaen kertomuksen loppuun ilmestyy vanhoja bylinoita, joissa ihaillaan pomorien merenkäyntitaitoja. Modernisaatio ei tässä ole lainkaan läsnä, päinvastoin, katse kääntyy menneisiin vuosisatoihin ja jo kuolleeseen runonlauluperinteeseen. Muutos on ajan venäläiselle kirjallisuudelle tyypillinen; kun usko modernisaation kautta saavutettavaan valoisaan tulevaisuuteen alkoi olla koetuksella, haettiin vastauksia sen sijaan menneisyydestä ja kadonneista tai katoamassa olevista perinteistä. Muutos ensimmäisen version paatokseen luonnonvarojen omistamisesta on jyrkkä, mutta ei uusikaan lopetus ympäristönsuojelun puolesta puhu.

Vuonna 1959 ilmestynyt kertomus "Dožd" ("Sade") puolestaan esittää modernisaation ulkopuolelta 1800-luvun loppupuolella saapuneena vitsauksena. Šerginin kertomuksissa (meri-) yhteydet ulkomaihin ovat alusta asti paljon esillä, mutta vasta tässä kertomuksessa niihin liittyy ajatus modernisaatiosta tuontitavarana. Ulkomaalaiset kauppiaat saapuvat Arkangeliin höyrylaivoilla ja kauppaavat nykyaikaisia kulutustavaroita, kuten ajanmukaisia naistenvaatteita. Tämä sarjatuotettu tuontitavara osoittautuu kuitenkin laadultaan kelvottomaksi, sillä vaatteiden värit katoavat sadevedessä. Toisin käy paikallisena käsityönä tuotetuille vaatteille, joissa on käytetty "äiti-maan luonnonvärejä: koivun ja haavan kuorta, santelipuuta, marjoja 
ja kasveja" (OMR, 102). Tässä kertomuksessa pohjoinen näyttäytyy eräänlaisena modernisaation uhrina, joka ei itse valinnut tulla hallituksi osana neuvostotilaa ja jonka tiiviiseen luontoyhteyteen perustuvat perinteet ovat jatkuvaan kehitykseen tähtäävää moderniteettia kestävämpi lähtökohta elämälle pohjoisessa.

\section{Pomorien hallitsema myyttinen Pohjola}

Boris Šerginin tuotannossa pomorit ottivat Pohjois-Venäjän haltuunsa jo keskiajalla. Haltuunotto tarkoittaa siinä sitä, että ankarista luonnonvoimista huolimatta ihmisasutus menestyi sopeutumalla elämään arktisen meren antimista ja sen ehdoilla. Suuri etäisyys muuhun Venäjään mahdollisti vanhan kulttuuriperinteen säilymisen pidempään kuin muualla. Harvat viittaukset Neuvostoliiton mukanaan tuomaan modernisaatioon ovat positiivisia, sen avulla ihminen voi hallita yhä ankarampia pohjoisia alueita, joilla ei-inhimillinen elämä ei menesty. 1940-luvulta alkaen luonnonvaroja ei kuitenkaan enää käsitellä ihmiselle itsesäänselvästi kuuluvana taloudellisena hyötynä.

Venäjän pohjoisen sakraalin maantieteen ja venäläisen kirjallisuuden pohjoisen tekstin keskeisenä tekijänä Šerginin tuotanto rakentaa pomorien narratiivista identiteettiä. Kuten Venäjän pohjoisen sakraalin maantieteen ja venäläisen kirjallisuuden pohjoisen tekstin tutkimus ovat osoittaneet, se vahvistaa myyttiä Venäjän Pohjolasta salaperäisenä aidon venäläisyyden sekä henkisyyden ja kristillisen moraalin tyyssijana, jossa luonnon ilmiöillä on uskonnollisia merkityksiä. Ympäristöeettiseltä kannalta sen kristilliset motiivit eivät ole johdonmukaisia, vaan viestivät toisinaan tarpeesta kestävään luonnonvarojen hyötykäyttöön ja joskus taas rohkaisevat yhä kasvavaan kehitykseen ihmisen ehdoilla. Šerginin pohjoista ei kuitenkaan voi pitä holistisena näkemyksenä siitä, mitä Venäjän Pohjola on, sillä siihen ei kuulu lainkaan sellaisia historiallisia tosiseikkoja kuin laajoilta alueilta sukupuuttoon metsästetyt eläinlajit, neuvostoaikaiset vankileirit tai Novaja Zemljalla 1950-luvun puolivälistä lukien tehdyt sadat ydinaseiden testiräjäytykset.

\section{Viitteet}

1 Kaikki suomennokset ovat omiani. - M.P.

2 Artikkeli on kirjoitettu osana Koneen Säätiön rahoittamaa hanketta Pohjoiset naapurit: Luonto ja ihminen Venäjän arktisen alueen kirjallisuuksissa (hankenumero 201803242).

3 Tarkkaan ottaen tässä kertomuksessa kyseessä on kielikuva kuolemisesta, joka representoituu siirtymänä hedelmällisemmille maille.

4 Venäjäksi promyšlennyi. Šerginin teoksissa tämä termi ei viittaa moderniin teolliseen tuotantoon, vaan jo vuosisatoja harjoitettuun ammattimaiseen kalastukseen ja merinisäkkäiden pyytämiseen.

5 Monissa slaavilaisissa kielissä tämä yhteys on säilynyt nykykielessä. Esimerkiksi ukrainaksi pohjoinen on північ ja puolaksi pólnoc.

6 Novgorodin Pyhän Sofian katedraali valmistui 1050-luvulla, ja sitä pidetään Venäjän vanhimpana rakennuksena. 
7 Kirjaimellisesti "kormštšik", joka juontaa veneenperää merkitsevästä sanasta "korma". Termi viittaa venearttelin tai artteliliittoutuman päähän" (Bernštam 1976, 62).

8 1930-luvun pohjoisen neuvostodiskurssissa yleistynyt venäjän sana osvojenije käännetään usein myös valloittamiseksi. Sen kantasanana on svoi, "oma", mikä viittaa omaksi tekemiseen tilallisessa merkityksessä. Tässä yhteydessä termi ei kuitenkaan viittaa valloittamiseen sotilaallisessa merkityksessä, vaan pikemminkin pohjoisen tilan hallintaan, haltuunottoon tai käyttöönottoon. Englanniksi Widdis $(2003,7)$ ja Bolotova $(2014,46-47)$ käyttävät vastinetta mastering.

\section{Lähteet}

\section{Aineisto}

GSM = Šergin, Boris (1971), Gandvik - studjonoje more. Arhangelsk: Severo-zapadnoje knižnoje izdatelstvo.

OMR = Šergin, Boris (1959), Okean-more russkoje. Pomorskije rasskazy. Moskva: Molodaja gvardija. Šergin, Boris (1957), Pomorskije byli i skazanija. Moskva: Detgiz.

Šergin, Boris (1924), U arhangelskogo goroda, u korabelnogo pristaništ ̌̌a. Sbornik starin. Moskva: Gosudarstvennoje izdatelstvo.

UPR = Šergin, Boris (1939), U pesennyh rek. Moskva: Gosudarstvennoje izdatelstvo "Hudožestvennaja literatura".

ZS = Šergin, Boris (1967), Zapetšatlennaja slava. Pomorskije byli i skazanija. Moskva: Sovetski pisatel.

\section{Kirjallisuus}

Anufrijev, V. V. (2013), Formirovanije pomorskogo etnokulturnogo tipa. - Kultura russkih pomorov. Red. V. V. Anufrijev, E. L. Bazarova, N. V. Bitsadze, N. N. Gontšarova, E. N. Selezneva \& P. Ju. Tšernosvitov. Moskva: FORUM, Neolit, 25-130.

Arhipova, A. \& Nekljudov, S. (2013), Folklor i vlast v "zakrytom obštšestve". - Russki polititšeski folklor. Issledovanija i publikatsii. Red. A. Pantšenko. Moskva: Novoje izdatelstvo, 32-75.

Bernštam, T. A. (1976), Metsästys ja kalastus. - Venäläinen perinnekulttuuri. Neuvostoliiton PohjoisEuroopan venäläisväestön etnologiaa 1800-luvulta 1900-luvun alkuun. Toim. K. V. Tšistov. Helsinki: Suomalaisen Kirjallisuuden Seura, 90-104.

Bolotova, Alla (2014), Conquering Nature and Engaging with the Environment in the Russian Industrialized North. Väitöskirja, Lapin yliopisto.

Brain, Stephen (2018), The Christian Environmental Ethic of the Russian Pomor. - Eurasian Environments: Nature and Ecology in Imperial Russian and Soviet History. Ed. Nicholas B. Breyfogle. Pittsburgh: University of Pittsburgh Press, 187-204.

Frank, Susi K. (2010), City of the Sun on Ice: The Soviet (Counter-)Discourse of the Arctic in the 1930s. - Arctic Discourses. Ed. J. Schimanski, H. Howlid Wærp \& A. Ryall. Newcastle upon Tyne: Cambridge Scholars Publishing, 106-131.

Frank, Susi K. (2017), Ice as a Literary Motif in Soviet Arctic Modernities. - Arctic Modernities: The Environmental, the Exotic and the Everyday. Ed. Heidi Hansson \& Anka Ryall. Newcastle: Cambridge Scholars Publishing, 16-38.

Galimova, Jelena (2013), Poezija prostranstva: obrazy morja, reki, lesa, bolota, tundry i motiv puti $v$ Severnom tekste russkoi literatury. Arhangelsk: KIRA.

Gamble, Christopher N., Joshua S. Hanan \& Thomas Nail (2019), What is New Materialism? - Angelaki 24:6, 111-134, DOI: 10.1080/0969725X.2019.1684704. 
Gorki, Maksim. (1931), O borbe s prirodoi. - Pravda \& Izvestija, 12.12.1931, http:/gorkiy-lit.ru/ gorkiy/articles/article-173.htm (Tarkistettu 11.11.2020).

Gorki, Maksim. (1933), O temah. - Pravda, Izvestija \& Literaturnaja gazeta, 17.10.1933, http://az.lib. ru/g/gorxkij_m/text_1933_o_temah.shtml (Tarkistettu 11.11.2020).

Hafstein, Valdimar Tr. (2014), The Constant Muse. Copyright and Creative Agency. - Narrative Culture 1:1, 9-48.

Horkova, M. V. (2010), Svojeobrazije skazok Borisa Šergina. - Filologija i tšelovek 2/2010, 157-162.

Ilin, M. (1931), New Russia's Primer. The Story of the Five-Year Plan. Käänt. George S. Counts. Boston: Houghton Mifflin Company.

Iovino, Serenella \& Serpil Oppermann (2014), Introduction: Stories Come to Matter. - Material Ecocriticism. Ed. Serenella Iovino \& Serpil Oppermann. Bloomington \& Indianapolis: Indiana University Press, 1-17.

Kaplin, A. D. (2014), Predislovije. - Ottsovo znanje. Pomorskije byli i skazanija. Boris Šergin. Moskva: Institut russkoi tsivilizatsii, 5-20.

Lahtinen, Toni ja Markku Lehtimäki (2007), Johdatus ekokriittiseen kirjallisuudentutkimukseen. Ä̈̈nekäs kevät. Ekokriittinen kirjallisuudentutkimus. Toim. Toni Lahtinen \& Markku Lehtimäki. Helsinki: Suomalaisen Kirjallisuuden Seura, 7-28.

Lajus, Julia (2018), Experts on Unknown Waters. - Eurasian Environments: Nature and Ecology in Imperial Russian and Soviet History. Ed. Nicholas B. Breyfogle. Pittsburgh: University of Pittsburgh Press, 205-220.

Lenin, V. I. (1970), Naše vnešneje i vnutrenneje položenije i zadatši Partii. - Polnoje sobranije sotšinenii. Tom 42. Izdanije pjatoje. Moskva: Izdatelstvo polititšeskoi literatury, 17-38, http:// bolshevick.org/teoriya-i-praktika-bolshevizma/lenin/42.pdf (Tarkistettu 4.11.2020).

Lihatšov, Dmitri (2004), Russki sever. http://likhachev.lfond.spb.ru/articl100/Russia/rus_sever.pdf (Tarkistettu 11.11.2020).

Lihatšov, D. \& Janin, V. (1986), Russki Sever kak pamjatnik otetšestvennoi i mirovoi kultury. - Kommunist 1/1986, 115-119.

Meljutina, M. N., L. D. Popova \& N. M. Terebihin (2016), Sakralnaja geografija i ierotopija Russkogo Severa. Arhangelsk: Severnyj (Arktitšeski) federalnyi universitet im. M.V. Lomonosova.

Nikitina, M. V. (2018), Obraz Arhangelskogo Severa v dnevnikah B. V. Šergina. - Kulturnoje nasledije Borisa Šergina i Jevgenija Kokovina. Sbornik materialov V Mežregionalnyh Šerginskih tštenii. Red. T. S. Rudnaja. Arhangelsk, 26-32.

Novikov, Dmitrii (2008), The Shotman Pomor'e Tales, or Myths of the New Realism. - Russian Studies in Literature 44:4 (Fall 2008), 63-68, DOI: 10.2753/RSL1061-1975440406.

Paasi, Anssi (2003), Region and Place: Regional Identity in Question. - Progress in Human Geography 27:4, 475-485, DOI: 10.1191/0309132503ph439pr.

Panchenko, Alexander A. (2005), The Cult of Lenin and "Soviet Folklore". - Folklorica 10:1, 18-38.

Raipola, Juha (2015), Ihmisen rajoilla. Epävarma tulevaisuus ja ei-inhimilliset toimijuudet Leena Krohnin Pereat Munduksessa. Väitöskirja, Tampereen yliopisto.

Ridanpää, Juha (2017), Imaginative regions. - The Routledge Handbook of Literature and Space. Ed. Robert T. Tally. London: Routledge, 256-266.

Ryall, Anka, Johan Schimanski \& Henning Howlid Wærp (2010), Arctic Discourses: An Introduction. - Arctic Discourses. Ed. J. Schimanski, H. Howlid Wærp \& A. Ryall. Newcastle upon Tyne: Cambridge Scholars Publishing, ix-xxii.

Said, Edward W. (2011), Orientalismi. Suom. Kati Pitkänen. Helsinki: Gaudeamus.

Solzhenitsyn, Aleksandr (1976), Vankileirien saaristo (Arhipelag GULAG) 1918-1956: Taiteellisen tutkimuksen kokeilu. Osat III Tappotyöleirit ja IV Sielu ja piikkilanka. Suom. Esa Adrian. Tampere: Kustannuspiste.

Terebihin, N. M. (1993), Sakralnaja geografija Russkogo Severa (Religiozno-mifologitšeskoje prostranstvo severnorusskoi kultury). Arhangelsk: Izdatelstvo pomorskogo meždunarodnogo pedagogitšeskogo universiteta imeni M. V. Lomonosova.

Terebihin, N. M. (2004), Metafizika Severa. Arhangelsk: Pomorski universitet.

Toporov, V. N. (2003), Peterburg i "Peterburgski tekst russkoi literatury" (Vvedenije v temu). Peterburgski tekst russkoi literatury. Izbrannyje trudy. Sankt-Peterburg: "Iskusstvo-SPB", 7-118.

Vlasova, I. V. \& T. A. Bernštam (1976), Maanomistusmuodot, yhteisö ja perhe. - Venäläinen perinnekulttuuri. Neuvostoliiton Pohjois-Euroopan venäläisväestön etnologiaa 1800-luvulta 1900-luvun 
alkuun. Toim. K. V. Tšistov. Helsinki: Suomalaisen Kirjallisuuden Seura, 42-70.

Vlasova, I. V. \& K. V. Tšistov (1976), SNTL:n Euroopan puolen pohjoisalueiden venäläisväestön muodostuminen. - Venäläinen perinnekulttuuri. Neuvostoliiton Pohjois-Euroopan venäläisväestön etnologiaa 1800-luvulta 1900-luvun alkuun. Toim. K. V. Tšistov. Helsinki: Suomalaisen Kirjallisuuden Seura, 18-38.

Weiskel, Timothy C. (1997), The Environmental Crisis and Western Civilization: The Lynn White Controversy, http://ecoethics.net/bib/1997/enca-001.htm (Tarkistettu 12.2.2021).

White, Lynn (1967), The Historical Roots of Our Ecologic Crisis. - Science 155:3767 (March 10, 1967), 1203-1207.

Widdis, Emma (2000), Borders: the aesthetic of conquest in Soviet cinema of the 1930s. - Journal of European Studies 30:120, 401-411, DOI: 10.1177/004724410003012004.

Widdis, Emma (2003), Visions of a New Land: Soviet Film from the Revolution to the Second World War. New Haven: Yale University Press.

Zubok, Vladislav (2017), The Idea of Russia. The Life and Work of Dmitry Likhachev. London, New York: I.B. Tauris. 